\title{
Effect of loperamide and naloxone on gastric acid secretion in healthy man
}

\author{
R CALDARA, * M CAMBIELli, E MASCI, M GUSLANDI, C BARBIERI, \\ AND C FERRARI \\ From the Second Department of Medicine, Fatebenefratelli Hospital, and the Third Medical Clinic, \\ University of Milan, Milan, Italy
}

SUMmary The effect of acute oral administration of three different doses $(4,8$, and $16 \mathrm{mg}) \mathrm{of}$ loperamide, a peripheral opiate agonist, on basal and submaximal pentagastrin-stimulated gastric acid secretion was evaluated in healthy volunteers. Both basal and stimulated gastric secretion were significantly lowered by 8 and $16 \mathrm{mg}$ of the drug in comparison with a control study, while $4 \mathrm{mg}$ was ineffective. Naloxone, a specific opiate antagonist, decreased slightly but not significantly both basal and pentagastrin-stimulated gastric acid secretion, when infused intravenously at the rate of $30 \mu \mathrm{g} / \mathrm{kg} / \mathrm{h}$, but completely abolished the inhibitory effect of loperamide on gastric acidity. These data also suggest that opiates may be involved in the regulation of gastric acid secretion in man by acting at a peripheral site, as loperamide does not cross the blood-brain barrier.

The effects of opiates on gastric secretion have recently been investigated. In man, both morphine and naloxone have been demonstrated to inhibit basal and meal-stimulated gastric acid secretion. ${ }^{1}$ Meperidine, another drug with opiate receptorstimulating properties, has been shown potently to reduce basal gastric acid secretion. ${ }^{2}$ In dogs, both morphine and met-enkephalin have been reported to enhance basal ${ }^{3-5}$ as well as histamine-stimulated ${ }^{45}$ gastric acid secretion. Conflicting results have been obtained after vagal and pentagastrin stimulation. as Magee ${ }^{4}$ reported that morphine inhibits both vagally and pentagastrin-stimulated gastric secretion, while a dose-dependent augmentation of pentagastrin-induced acid secretion by morphine and met-enkephalin was observed by Konturek et $a l .$, an effect which was suppressed by naloxone, an opiate antagonist, as well as by metiamide and atropine. $^{5}$ In cats neither met-enkephalin nor naloxone altered the gastric acid secretion. ${ }^{6}$

Loperamide is a new opiate constipating agent, now widely used in the treatment of diarrhoea. ${ }^{7}$ The drug strongly inhibits gastrointestinal motility, an effect qualitatively similar to that exhibited by morphine and completely blocked by naloxone. ${ }^{8}$

*Address for reprint requests: Dr R Caldara, Second Department of Medicine. Fatebenefratelli Hospital, Corso di Porta Nuova 23. 20121 Milano, Italy.
Loperamide, unlike the other opiates, ${ }^{9}{ }^{10}$ does not cross the blood-brain barrier. ${ }^{11}$

The aim of the present study was to evaluate the effect of loperamide alone, naloxone alone, and of a combination of the two drugs, on basal and submaximal pentagastrin-stimulated gastric acid secretion in healthy man.

\section{Methods}

Thirty-seven healthy subjects who had no history of gastrointestinal diseases volunteered for the study. There were 17 women and 20 men, aged $21-55$ years (mean, 42 years). Informed consent was obtained from all subjects and the research was carried out according to the Declaration of Helsinki.

After an overnight fast, a nasogastric tube was passed into the stomach and its position was checked by fluoroscopy. Gastric juice collected by continuous aspiration was pooled in 15 minute fractions. In a group of 21 subjects both basal and submaximal pentagastrin (infused intravenously at the rate of $0.25 \mu \mathrm{g} / \mathrm{kg} / \mathrm{h}$ )-stimulated gastric acid secretion were evaluated for one hour each, after the first 30 minute portion had been discarded. Either placebo or loperamide at a dose of 4,8 , or $16 \mathrm{mg}$ was administered orally $2 \cdot 5$ hours before the intubation. Each experiment was performed in 
seven different subjects. In the other 16 subjects either basal $(\mathrm{N}=8)$ or pentagastrin $(0 \cdot 25 \mu \mathrm{g} / \mathrm{kg} / \mathrm{h})$ stimulated $(\mathrm{N}=8)$ gastric acid secretion was evaluated after the first 30 minute portion, both in the basal and in the pentagastrin study, had been discarded. During the second hour naloxone was infused at the rate of $30 \mu \mathrm{g} / \mathrm{kg} / \mathrm{h}$. On separate days these studies were repeated in the same subjects after oral administration of either placebo or loperamide $8 \mathrm{mg} 2.5$ hours before the intubation. All these tests were carried out in randomised order at a five day interval.

Gastric acid concentration was measured by titration with $0 \cdot 1 \mathrm{M} \mathrm{NaOH}$ to $\mathrm{pH} 7 \cdot 0$ using a semiautomatic titrameter. Statistical analysis was performed by the two-tailed Student's $t$ test for paired data and by the analysis of covariance for repeated measures within and between subjects, followed by Turkey's $t$ test for multiple comparisons as appropriate. The differences in basal acid secretion values. which are not normally distributed, were evaluated by a non-parametric test, the Mann-Whitney $U$ test. P values of $<0.05$ were considered to be significant.

\section{Results}

No side-effects were reported by any subject.

Whereas loperamide $4 \mathrm{mg}$ did not significantly modify gastric acid secretion, 8 or $16 \mathrm{mg}$ of the drug significantly decreased basal and submaximal pentagastrin-stimulated gastric acid output and juice volume as compared with the placebo study (Table 1). Gastric acid output and juice volume in basal conditions were decreased by approximately $45 \%$ after $8 \mathrm{mg}$ loperamide and by $60 \%$ after $16 \mathrm{mg}$, whereas, after stimulation, gastric acid output as

Table 1 Effect of acute oral administration of different doses of loperamide or placebo on basal and pentagastrin $(0.25 \mu \mathrm{g} / \mathrm{kg} / \mathrm{h})$-stimulated gastric acid output and juice volume in healthy volunteers (mean $\pm S E)$

\begin{tabular}{|c|c|c|c|c|c|}
\hline \multirow[t]{2}{*}{$\begin{array}{l}\text { Subjects } \\
\text { (no.) }\end{array}$} & \multirow[t]{2}{*}{ Drus } & \multicolumn{2}{|c|}{$\begin{array}{l}\text { Acid output } \\
(\mathrm{mmol} / \mathrm{h})\end{array}$} & \multicolumn{2}{|l|}{$\begin{array}{l}\text { lolume } \\
(m / / h)\end{array}$} \\
\hline & & Basal & Srimulated & Basal & Stimulated \\
\hline \multirow[t]{2}{*}{7} & Placebo & $3.0: 0.4$ & $16 \cdot 0: 3.0$ & $55: 8$ & $153: 18$ \\
\hline & $\begin{array}{l}\text { Loperamide } \\
\text { (4 mg) }\end{array}$ & $2 \cdot 9=0 \cdot 3$ & $15 \cdot 8: 3 \cdot 0$ & $56: 10$ & $146: 13$ \\
\hline \multirow[t]{2}{*}{7} & Placebo & $3 \cdot 3 \cdot 0 \cdot 5$ & $16 \cdot 6: 2 \cdot 4$ & $58: 7$ & $157: 20$ \\
\hline & $\begin{array}{l}\text { Loperamide } \\
\text { (8 mg) }\end{array}$ & $1.9: 0.5 *$ & $12 \cdot 4: 1.9^{*}$ & $32 \div 7^{*}$ & $118: 14^{*}$ \\
\hline \multirow[t]{2}{*}{7} & Placebo & $3 \cdot 2: 0 \cdot 5$ & $16.9: 2.8$ & $56: 9$ & $150: 16$ \\
\hline & $\begin{array}{l}\text { Loperamide } \\
\qquad(16 \mathrm{mg})\end{array}$ & $1 \cdot 4: 0 \cdot 3 \dagger$ & $10 \cdot 3: 3 \cdot 0^{*}$ & $24: 4 \dagger$ & $82=10 \dagger$ \\
\hline
\end{tabular}

well as juice volume were reduced by $25 \%$ with $8 \mathrm{mg}$ loperamide and by $35 \%$ with $16 \mathrm{mg}$. Analysis of the between drug doses revealed the existence of significant differences only between 4 and $16 \mathrm{mg}$ of loperamide: gastric acid output was further reduced by $16 \mathrm{mg}$ of the drug both in basal conditions and after stimulation $(\mathrm{P}<0.05)$, and juice volume was even more markedly decreased $(\mathrm{p}<0 \cdot 01$ for basal values, $\mathrm{P}<0 \cdot 02$ after stimulation).

Table 2 Effect of naloxone infusion $(30 \mu \mathrm{g} / \mathrm{kg} / \mathrm{h})$ or placebo on basal and pentagastrin $(0 \cdot 25 \mu \mathrm{g} / \mathrm{kg} / \mathrm{h})$ stimulated gastric acid output and juice volume in eight healthy volunteers

\begin{tabular}{|c|c|c|c|c|}
\hline \multirow[t]{2}{*}{ Drus } & \multicolumn{2}{|c|}{$\begin{array}{l}\text { Acid output } \\
(\mathrm{mmol} / \mathrm{h})\end{array}$} & \multicolumn{2}{|c|}{$\begin{array}{l}\text { lolume } \\
(m l / h)\end{array}$} \\
\hline & Basal & Stimulated & Basal & Stimulated \\
\hline Placebo & $3 \cdot 0: 0.5$ & $15 \cdot 5 \cdot 2 \cdot 8$ & $51: 8$ & $148 \cdot 18$ \\
\hline Nalaxone & $2 \cdot 4 \cdot 0 \cdot 7$ & $13 \cdot 3 \cdot 2 \cdot 9$ & $36 \cdot 9$ & $130 \cdot 16$ \\
\hline
\end{tabular}

No significant diflerences were obsersed between naloxone and placebo study. 
Naloxone infusion decreased slightly but not significantly both basal (acid output, $\mathrm{P}=0.25$; juice volume, $\mathrm{P}=0 \cdot 18$ according to Mann-Whitney $U$ test) and pentagastrin-stimulated (acid output, $\mathrm{P}=0 \cdot 48$; juice volume, $\mathrm{P}=0.35$ according to Student's $t$ test) gastric acid secretion in comparison with placebo (Table 2). The inhibitory effect of loperamide pretreatment was abolished by naloxone, the values of gastric acid secretion returning to the placebo rates (Figs. 1 and 2).

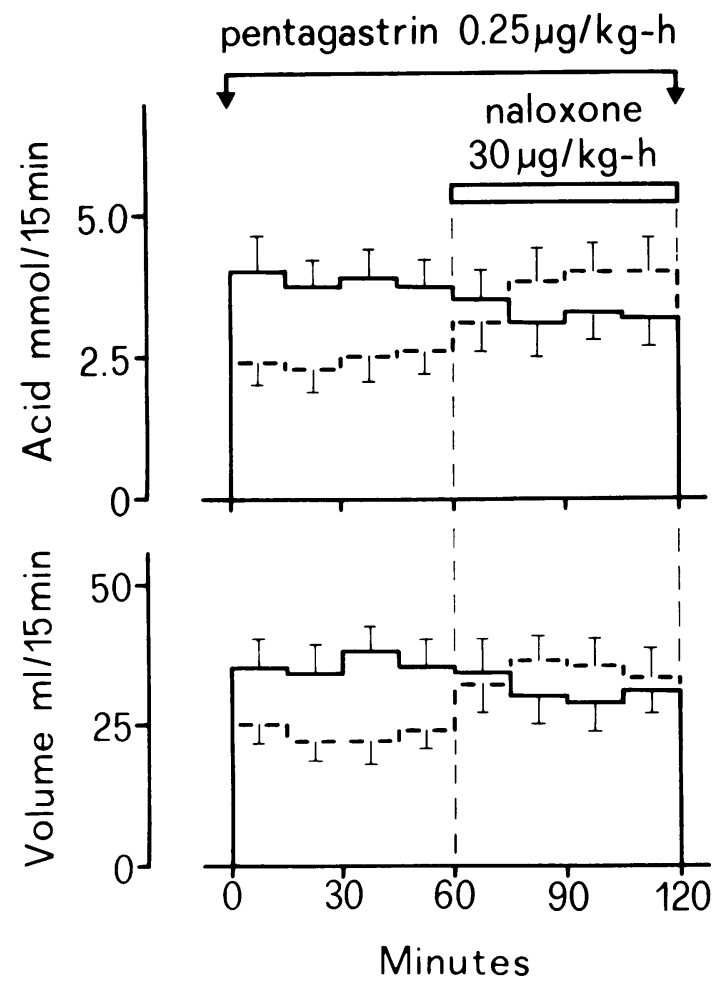

Fig. 2 Mean $\pm S E$ values of pentagastrin-stimulated gastric acid output and juice volume before and during naloxone infusion after placebo (-) or loperamide $8 \mathrm{mg}$ $(---)$ orally administered $2 \cdot 5$ hours before intubation in eight healthy subjects.

\section{Discussion}

The present study shows that acute loperamide administration is associated with decreased basal and submaximal pentagastrin-stimulated gastric acid secretion at drug doses of 8 and $16 \mathrm{mg}$, but not at the lowest dose of $4 \mathrm{mg}$, which is, however, able strongly to inhibit peristaltic gut activity, ${ }^{12}$ possibly via stimulation of specific opiate receptors. ${ }^{8}$
Loperamide, even at large doses, does not exert central opiate activity. ${ }^{13}$ Stahl et al. ${ }^{14}$ provided evidence that, although the drug shows high affinity binding to opiate receptors in brain homogenate, it does not produce narcotic-like action after in vivo systemic administration, because of its poor penetration through the blood-brain barrier. ${ }^{11}$

The present results are in agreement with human studies showing reduced gastric acid output by intramuscular administration of meperidine, ${ }^{2}$ another opiate agonist, and by intravenous infusion of morphine. ${ }^{1}$ The mechanism of action of these drugs has been attributed to an anticholinergic effect, either via reduction of the release rate of acetylcholine from nerve endings ${ }^{12}$-an action common to other exogenous opiates ${ }^{16}$-or through blockade of muscarinic receptors. ${ }^{2}$ While a specific role of opiate receptors per se has not been considered in the meperidine study, ${ }^{2}$ the hypothesis that direct stimulation of opiate receptors may instead be responsible has been ruled out on the basis of the author's finding that even naloxone alone was able to inhibit gastric acid secretion. ${ }^{1}$ However, the effect of morphine plus naloxone has not been investigated in that study.

Loperamide is a synthetic opiate agonist which, similarly to other opiates, has been shown to inhibit acetylcholine release in guinea-pig ileum and does not seem to possess other pharmacological properties except a weak antihistaminic effect at high drug concentration. ${ }^{17}$ The present finding of complete reversal of loperamide inhibition of gastric acid secretion by concomitant naloxone infusion strongly suggests that opiate receptor stimulation is indeed the mechanism by which loperamide acts on the stomach. Although naloxone alone failed to lower significantly gastric acidity in our study, a trend downward was observed both in basal and pentagastrin-stimulated acid secretion. The partial disagreement with the data by Feldman et al. ${ }^{1}$ depends on the failure of two of eight subjects to show an antisecretory response to naloxone. Although the similarity of the effects induced by an opiate agonist and the antagonist naloxone on gastric secretion seems quite paradoxical, similar effects on lower oesophageal sphincter pressure in the opossum and on gastric emptying rate in man have been obtained with morphine or naloxone administration; ${ }^{18} 19$ moreover, the morphine effect on the oesophagus has been antagonised by naloxone. ${ }^{18}$ As higher doses of naloxone than those used in the present investigation are needed to inhibit opiate $\delta$ receptors, while $\mu$ receptors are responsive to small doses,${ }^{20}$ the possibility that higher drug doses may stimulate gastric acid secretion remains to be evaluated. 
The present results, as well as those reported with meperidine and morphine in man, ${ }^{12}$ do not agree with studies showing increased gastric acid secretion by morphine and met-enkephalin in $\operatorname{dogs}^{3-5}$ and lack of effect in cats. ${ }^{6}$ This discrepancy may probably be related either to the different animal species, or to the different doses of drug and routes of administration.

The finding that a peripherally acting opiate agonist like loperamide is able to inhibit gastric acid secretion supports the hypothesis of Solomon ${ }^{21}$ that the effects of exogenous and endogenous opiates on the stomach are not centrally mediated.

The authors thank Dr M Recchia, Mario Negri Institute for Pharmacological Research, Milan, Italy, for statistical advice, and Gentili spa, Pisa, Italy, for the generous supply of loperamide and Crinos spa, Como-Villaguardia, Italy, for the kind gift of naloxone.

\section{References}

'Feldman M, Walsh JH, Taylor IL. Effect of naloxone and morphine on gastric acid secretion and on serum gastrin and pancreatic polypeptide concentrations in humans. Gastroenterology 1980; 79: 294-8.

${ }^{2}$ Meeroff JC, Garcia Fernandez G, Gaon D. Potent reduction of basal acid output produced by meperidine. Dig Dis Sci 1978; 23: 696-8.

${ }^{3}$ Yamaguchi I. A comparative study on the mechanism of action of morphine on gastric acid secretion in dogs. Jpn J Pharmacol 1974; 24: 779-86.

${ }^{4}$ Magee DF. Action of morphine sulphate on stimulated gastric secretion in dogs. Gastroenterology 1975; 68: 1340-3.

${ }^{5}$ Konturek SJ, Tasler J, Cieszkowski M, Mikos E, Coy DH, Schally AV. Comparison of methionine-enkepHalin in the stimulation of gastric acid secretion in the dog. Gastroenterology 1980; 78: 294-300.

${ }^{6}$ Gascoigne AD, Hirst BH, Reed JD, Shaw B. Effects of thyrotrophin-releasing hormone, and methionineenkephalin on gastric acid and pepsin secretion in the cat. Br J Pharmacol 1980; 69: 527-34.

${ }^{7}$ Heel RC, Brogden RN, Speight TM, Avery GS. Loperamide: a review of its pharmacological properties and therapeutic efficacy in diarrhoea. Drugs 1978; 15: 33-52.
${ }^{\text {}}$ Mackerer CR, Clay GA, Dajani EZ. Loperamide binding to opiate receptor sites of brain and myenteric plexus. J Pharmacol Exp Ther 1976; 199: 131-6.

${ }^{9}$ Kastin AJ, Nissen C, Schally AV, Coy DH. Blood brain barrier half-time disappearance and brain distribution of labeled enkephalin and potent analog. Brain Res Bull 1977; 1: 583-9.

${ }^{10}$ Cornford EM, Braun LD, Crane PD, Oldendorf WH. Blood-brain barrier restriction of peptides and the low uptake of enkephalins. Endocrinology 1978; 103: 1297303.

${ }^{11}$ Heykants J, Michiels M, Knaeps A, Brugmans J. Loperamide ( $\mathrm{R}$ 18553), a novel type of antidiarrheal agent. Part 5: The pharmacokinetics of loperamide in rats and man. Arzneim Forsch 1974; 24: 1649-53.

${ }^{12}$ Schuermans V, van Lommel R, Dom J, Brugmans J. Loperamide ( $R$ 18553), a novel type of antidiarrheal agent. Part 6: Clinical pharmacology. Placebo-controlled comparison of the constipating activity and safety of loperamide, diphenoxylate and codeine in normal volunteers. Arzneim Forsch 1974; 24: 1653-7.

${ }^{13}$ Colpaert FC, Niemegeers CJE, Lal H, Janssen PAJ. Investigations on drug produced and subjectively experienced discriminative stimuli. 2. Loperamide, an antidiarrhoea devoid of narcotic cue producing action. Life Sci 1975; 16: 717-23.

${ }^{14}$ Stahl KD, van Bever W, Janssen P, Simon EJ. Receptor affinity and pharmacological potency of a series of narcotic analgesic, antidiarrheal and neuroleptic drugs. Eur J Pharmacol 1977; 46: 199-205.

${ }^{15}$ Lien EL, Morrison A, Dvonch W. The effects of partial opiate agonists on plasma prolactin and growth hormone levels in the rat. Life Sci 1979; 25: 1709-15.

${ }^{16}$ Ambinder RF. Schuster MM. Endorphine: new gut peptides with a familiar face. Gastroenterology 1979; 77: $1132-40$.

${ }^{17}$ Van Nueten JM, Janssen PAJ, Fontaine J. Loperamide (R 18553), a novel type of antidiarrheal agent. Part 3: In vitro studies on the peristaltic reflex and other experiments on isolated tissues. Arzneim Forsch 1974; 24: 1641-5.

${ }^{\mathrm{rx}}$ Rattan S, Goyal RK. Effect of morphine and endogenous opiates on the opossum lower esophageal sphincter. Gastroenterology 1980; 78: 1241 A.

${ }^{19}$ Champion M, Sullivan S, Chamberlain M, Vezina W. Morphine and naloxone inhibit gastric emptying. Gastroenterology 1980; 78: 1149 A.

${ }^{20}$ Chang KW, Cuatrecasas P. Multiple opiate receptors. Enkephalins and morphine bind to receptors of different specificity. J Biol Chem 1979; 254: 2610-6.

${ }^{2}$ Solomon TE. Endogenous opiates and gastric acid secretion. Gastroenterology 1980; 78: 411-3. 